\title{
KONTRIBUSI LABORATORIUM KOMPUTER, INTERNET DAN MOTIVASI BERPRESTASI TERHADAP HASIL BELAJAR SISWA RPL SE-KABUPATEN BANTUL
}

\author{
Slamet Pujiono \\ SMK Negeri 1 Sanden \\ slamet.pujiono@gmail.com \\ Eko Marpanaji \\ Universitas Negeri Yogyakarta \\ eko@uny.ac.id \\ Abstrak
}

\begin{abstract}
Tujuan penelitian ini adalah: (1) mengetahui kontribusi manajemen operasi laboratorium, (2) pemanfaatan internet, dan (3) motivasi berprestasi terhadap hasil belajar siswa jurusan RPL seKabupaten Bantul. Metode pengumpulan data menggunakan tes dan kuesioner. Statistik inferensial digunakan dengan metode analisis deskriptif dan analisis regresi. Hasil penelitian menunjukkan bahwa (1) manajemen operasi laboratorium komputer cenderung pada kategori sangat baik; (2) Pemanfaatan internet cenderung pada kategori buruk; (3) motivasi berprestasi cenderung pada kategori baik; (4) hasil belajar cenderung pada kategori cukup. Pengujian hipotesis menunjukkan bahwa (1) terdapat kontribusi positifdan signifikan antara manajemen operasi laboratorium komputer dengan hasil belajar siswa; (2) terdapat kontribusi positif dan signifikan antara pemanfaatan internet dengan hasil belajar siswa; (3) terdapat kontribusi positif dan signifikan antara motivasi berprestasi dengan hasil belajar siswa; (4) terdapat kontribusi positif dan signifikan antara manajemen operasi laboratorium komputer, pemanfaatan internet dan motivasi berprestasi dengan hasil belajar siswa SMK jurusan RPL se-Kabupaten Bantul.
\end{abstract}

Kata kunci: manajemen operasi laboratorium komputer, pemanfaatan internet, motivasi berprestasi, hasil belajar

\section{THE CONTRIBUTIONS OF COMPUTER LABORATORY, THE INTERNET AND ACHIEVEMENT MOTIVATION TO STUDENT'S ACHIEVEMENT OF SOFTWARE ENGINEERING DEPARTMENT IN THE DISTRICT OF BANTUL}

\begin{abstract}
This research is aimed to: (1) find out the contribution of laboratory operation management, (2) the use of internet, and (3) the achievement motivation on the students learning outcomes in Software Engineering in Bantul district. Questionnaire and test was used to explore the data. Inferential statistic was used with the descriptive analyse and multiple linier regression analayse. to test the validity and reliability of the research instruments. The results obtained are as follows: (1) The score of the computer lab operation management is at a very good category. (2) The score of the use of the internet is at poor category. (3) Achievement motivation scores obtain good category. (4) The score of the variables of outcome studied at fairl category. Hypothesis testing shows the following result: (1) There is a positive and significant contribution of the operations labs computer management to student learning outcomes; (2) There is a positive and significant contribution of the use of the internet to student learning outcomes; (3) There is a positive and significant contribution of the achievement motivation to student learning outcomes; (4) There is a positive and significant contribution of the operation management of computer laboratory, internet utilization and achievement motivation to student learning outcomes of vocational students majoring in Software Engineering in Bantul district.
\end{abstract}

Keywords: computer laboratory operation management, internet utilization, achievement motivation, student's achievement 


\section{PENDAHULUAN}

Manajemen laboratorium yang baik sangat penting dalam menjamin berlangsungnya kegiatan pembelajaran. Direktorat Jenderal Pendidikan Menengah Kementerian Pendidikan dan Kebudayaan telah mengeluarkan panduan teknis perawatan laboratorium komputer dan multimedia yang mencakup empat kegiatan utama yaitu: (1) perencanaan; (2) pengelolaan; (3) perawatan; (4) keberlanjutan. Menurut Nurohman (2013, pp. 3-7), dalam setiap laboratorium terdiri atas koordinator laboratorium, kepala laboratorium, teknisi, dan laboran yang masing-masing mempunyai tugas yang besar dan tanggungjawab yang spesifik.

Data observasi awal di seluruh Sekolah Menengah Kejuruan (SMK) yang mempunyai jurusan Rekayasa Perangkat Lunak (RPL) seKabupaten Bantul diketahui bahwa sebagian besar SMK mempunyai jumlah personal yang terbatas sebagai pengelola laboratorium, baik dari sisi jumlah maupun tingkat kompetensinya. Mengacu pada Permendiknas Nomor 24 tahun 2007, standar ruang laboratorium yang ideal adalah $30 \mathrm{~m}^{2}$ dan lebar $5 \mathrm{~m}$ yang digunakan untuk 15 siswa dengan rasio minimum luas ruang laboratorium komputer adalah $2 \mathrm{~m}^{2} /$ peserta didik. Selain itu, 4 dari 6 SMK yang diobservasi mengalami keterbatasan jumlah komputer. Beberapa sekolah juga mengalami kendala lebar pita (bandwidth) internet. Keterbatasan bandwidth sangat berpengaruh terhadap kecepatan akses internet yang menyebabkan menurunnya animo pemanfaatan internet (Amperiyanto, 2004, p.2), baik bagi guru maupun siswa dalam mencari sumber belajar.

Kecepatan akses internet yang ideal untuk memenuhi tuntutan saat ini adalah 3 Megabits per second (Mbps) untuk setiap unit komputer (Noor, 2011). Sedangkan menurut Horton dan Horton (2003, p.91), bahwa akses internet yang baik jika pada sebuah komputer dengan kapasitas bandwith setara dengan 14.4 kbps (kilo bit per second).

Upaya yang telah dilakukan Pemerintah untuk mempermudah akses internet ke sekolah adalah dengan menyediakan jaringan internet gratis ke sekolah. Tujuan utama dari pembangunan jaringan tersebut adalah: (1) peningkatan pemerataan dan perluasan akses pendidi- kan, (2) peningkatan mutu, relevansi, dan daya saing pendidikan, (3) penguatan tata kelola, akuntabilitas, dan citra publik pengelolaan pendidikan (Purbo, 2007). Namun demikian, permasalahan baru yang muncul terhadap operasional jaringan internet adalah: (1) dukungan teknisi yang sangat kurang; (2) jaringan sering mati; (3) kapasitas bandwidth yang dibagikan terlalu kecil sehingga jika kapasitas jaringan yang ada di-share dengan warga sekolah lain maka pada saat berselancar internet akan terasa sangat lambat.

Menurut Hakam (2011), bahwa konvergensi media terjadi melalui penggunaan internet mampu dioperasikan, meskipun belum bekerja maksimal. Sriyana (2010, pp.79-103) memaparkan bahwa salah satu pemanfaatan internet pada UKM di Bantul melalui peningkatan akses teknologi. Ambar Sari Dewi, penerima Google Policy Research Followship 2012 menjelaskan bahwa adopsi Teknologi Informasi dan Komunikasi (TIK) oleh UKM masih kurang dalam hal pemanfaatan internet (Adopsi TIK oleh UKM, pemanfaatan internet masih kurang, 2013). Zainuddin (2006, p.47) menyebutkan bahwa internet sangat berpengaruh terhadap proses pembelajaran. Hasil penelitiannya membuktikan bahwa responden yang menyatakan tidak ada pengaruh pemanfaatan internet terhadap keberhasilan studi sebanyak $10 \%$.

Internet saat ini juga marak digunakan sebagai media aktualisasi diri di media sosial (social media) dan Indonesia menempati peringkat 4 pengguna facebook (Pengguna internet Indonesia 63 juta orang, 2013). Dengan fenomena tersebut, lahirlah media pembelajaran berbasis media sosial yang dikenal dengan Edmodo (www.edmodo.com). Dengan munculnya Edmodo diharapkan siswa akan tertarik dan merasa nyaman untuk belajar seperti mereka menggunakan media sosial.

Belajar adalah sebuah bentuk social actions seseorang yang memperhitungkan faktor eksternal dan faktor internal (Neisser, 1993, p.68). Salah satu faktor internal dalam proses pembelajaran adalah motivasi untuk mencapai prestasi. Penelitian Barakatu (2007, p.48) mengungkapkan bahwa guru berperan besar dalam mengembangkan self efficacy siswa melalui rancangan pembelajaran yang dituangkan 
dalam prosedur instruksional sehingga akan mengembangkan hasil belajar dan motivasi berprestasi siswa untuk kegiatan belajar berikutnya. Namun demikian, selama ini belum ada penelitian sejenis guna mengungkapkan seberapa besar tingkat motivasi berprestasi di jurusan RPL se-Kabupaten Bantul.

Hasil belajar adalah bagian penting lainnya dari sebuah proses pembelajaran. Hasil belajar harus tercermin dari aspek kognitif, afektif, dan psikomotorik. Salah satu cara untuk melihat hasil belajar siswa pada ranah kognitif melalui nilai tes. Namun demikian ,perolehan hasil belajar di Kabupaten Bantul dalam kurun waktu 2011 - 2014 selalu menurun (Daftar sekolah SMK peringkat propinsi berdasarkan jumlah nilai tes penjajakan Ujian Nasional SMK tahun pelajaran 2011/2012, 2012; Kurniawan, 2011; Suharjono \& Hidayat, 2012; Rusqiyanti, 2013; Kurniawan, 2014).

Menurut Prosser (1950, p.217), bahwa pembelajaran yang baik untuk dilaksanakan di SMK adalah pembelajaran yang metode dan suasananya sama dengan yang ada di industri. Sedangkn menurut Alderman (2004, pp.7-9), bahwa model pembelajaran tingkat sebaya sangat efektif untuk membantu dalam memotivasi siswa agar lebih mampu. Horton dan Horton (2003, pp.29-32) mengungkapkan bahwa akhir-akhir ini penggunaan e-learning yang dahulunya berupa Computer Based Training (CBT) menjadi Web Based Training (WBT). Mengacu uraian yang disampaikan dari berbagai kendala dan teori dasar di atas menyebabkan peneliti memandang perlu adanya penelitian untuk mengetahui seberapa besar kontribusi dari manajemen operasi laboratorium komputer, pemanfaatan internet, dan motivasi berprestasi terhadap hasil belajar siswa jurusan RPL seKabupaten Bantul untuk segera dilakukan.

\section{METODE PENELITIAN}

\section{Jenis Penelitian}

Penelitian ini dilakukan dengan menggunakan pendekatan kuantitatif. Ditinjau dari cara pengungkapan hasil penelitian, maka penelitian ini adalah penelitian inferensial hipotetik yang berusaha mengungkapkan faktafakta aktual (ex-post facto) dan dengan sifat populasi tertentu melalui proses penelitian, pengolahan data dan penyajian data penelitian yang disusun secara sistematis. Penyajian yang sistematis tersebut sesuai dengan aturan penulisan karya ilmiah yang telah ditentukan.

\section{Waktu dan Tempat Penelitian}

Penelitian dilaksanakan selama 3 bulan, yaitu pada bulan Maret 2014 dan berakhir pada bulan Juni 2014. Tempat penelitian adalah seluruh SMK di Kabupaten Bantul yang mempunyai program keahlian RPL yang berjumlah 6 sekolah.

\section{Target/Subjek Penelitian}

Mengacu makna populasi menurut Muijs (2004, p.15) dan Sudjana (1992, p.6), maka populasi penelitian ini adalah seluruh siswa SMK di Kabupaten Bantul pada program keahlian RPL tingkat XI sejumlah 275 siswa. Pemilihan siswa tingkat XI dikarenakan pada jenjang tersebut sudah diberikan bekal yang cukup tentang pemanfaatan teknologi informasi melalui mata diklat dasar kompetensi kejuruan program keahlian RPL.

Menurut Sujarweni (2007, p.10) dan Muijs $(2004$, p. 8$)$, penentuan sampel dengan membandingkan 5 metode yaitu: 1) menggunakan rumus Slovin diperoleh 163 sampel; 2) melalui tabel Isac dan Michael diperoleh 154 sampel; 3) menggunakan nomogram Herry King diperoleh 138 sampel; 4) menggunakan tabel Krejcie-Morgan diperoleh 160 sampel; dan 5) menggunakan tabel Cohen Manion dan Morrison diperoleh 159 sampel. Jumlah sampel yang digunakan pada penelitian ini mengacu pada hasil perhitungan dengan rumus Slovin yang merupakan perolehan terbanyak dari metode yang lainnya. Tabel 1 menyajikan detail jumlah sampel yang diambil pada setiap sekolah.

Tabel 1. Jumlah sampel

\begin{tabular}{clc}
\hline No & Nama Sekolah & Sampel \\
\hline 1 & SMK Muh. 1 Bantul & 47 \\
2 & SMK Muh. 2 Bantul & 18 \\
3 & SMK N 1 Sanden & 9 \\
4 & SMK Muh. Bambanglipuro & 36 \\
5 & SMK N 1 Pajangan & 36 \\
6 & SMK Muh. Kretek & 17 \\
\hline Jumlah & $\mathbf{1 6 3}$ \\
\hline
\end{tabular}




\section{Prosedur}

Teknik pengambilan sampel secara simple random sampling. Pengumpulan data menggunakan instrumen penelitian melalui survey (Riduwan, 2008, p.49). Analisis data bersifat statistik dengan tujuan untuk menguji hipotesis yang telah ditetapkan.

\section{Data, Intrumen, dan Teknik Pengumpulan Data}

Mengacu pada pengertian variabel menurut Muijs (2004, p.8), penelitian ini terdiri 3 variabel bebas, yaitu: 1) manajemen operasi laboratorium komputer $\left(\mathrm{X}_{1}\right)$, 2) pemanfaatan internet $\left(\mathrm{X}_{2}\right)$, dan 3$)$ motivasi berprestasi $\left(\mathrm{X}_{3}\right)$. Variabel terikat pada penelitian ini adalah hasil belajar siswa (Y). Pengumpulan data pada variabel bebas menggunakan kuesioner. Untuk variabel bebas X1 dan X2 kuesioner disusun berdasarkan landasan teori yang digunakan, sedangkan untuk X3 kuesioner dikembangkan dari kisi-kisi model Attention Relevance Confidence Satisfaction (ARCS) yang dibuat oleh Keller (1987). Variabel terikat pengumpulan data menggunakan tes.
Validitas penelitian ini menggunakan validitas isi dan validitas konstruk (Carmines \& Zeller, 1979, pp.17-28). Pertimbangan para ahli dilakukan pada validitas isi, sedangkan validitas konstruk menggunakan rumus korelasi pearson's product moment dengan taraf signifikansi sebesar 5\% (Sujarweni, 2007, p.187). Pada penelitian ini, uji reliabilitas dilakukan secara bersama-sama terhadap seluruh butir pertanyaan dengan menggunakan teknik alpha cronbach, sedangkan instrumen tes hasil belajar menggunakan uji tingkat kesukaran dan daya beda.

\section{Teknik Analisis Data}

Penelitian ini menggunakan statistik inferensial. Penyajian data penelitian dengan menggunakan analisis deskriptif melalui tabel, diagram, menghitung mean (skor rerata) sebagai norma perbandingan dengan menggunakan tabel sigma pada rentang 1,2 dengan lima kategori, modus, median dan simpangan baku. Lima rentang kategori yang dimaksud tersaji pada Tabel 2 berikut.

Tabel 2. Konversi skor ideal kedalam kategori nilai

\begin{tabular}{clc}
\hline Nilai & Skor & Kategori \\
\hline 5 & $\mathrm{X}>\mathrm{M}_{\mathrm{i}}+1,80 \mathrm{SD}_{\mathrm{i}}$ & Sangat Baik \\
4 & $\mathrm{M}_{\mathrm{i}}+0,60 \mathrm{SD}_{\mathrm{i}}<\mathrm{X} \leq \mathrm{M}_{\mathrm{i}}+1,80 \mathrm{SD}_{\mathrm{i}}$ & Baik \\
3 & $\mathrm{M}_{\mathrm{i}}-0,60 \mathrm{SD}_{\mathrm{i}}<\mathrm{X} \leq \mathrm{M}_{\mathrm{i}}+0,60 \mathrm{SD}_{\mathrm{i}}$ & Cukup \\
2 & $\mathrm{M}_{\mathrm{i}}-1,80 \mathrm{SD}_{\mathrm{i}}<\mathrm{X} \leq \mathrm{M}_{\mathrm{i}}-0,60 \mathrm{SD}_{\mathrm{i}}$ & Buruk \\
1 & $\mathrm{X} \leq \mathrm{M}_{\mathrm{i}}-1,80 \mathrm{SD}_{\mathrm{i}}$ & Sangat Buruk \\
\hline
\end{tabular}

Variabel manajemen operasi laboratorium dan pemanfaatan internet menggunakan penskalaan interval dengan pemberian skala untuk masing-masing instrumen tersaji pada Tabel 3. Pernyataan yang dibuat terbagi menjadi 2 jenis, yaitu pernyataan positif dan pernyataan negatif. Pernyataan positif yang paling sesuai dengan kenyataan diberi skor tertinggi, yaitu 5 , dan pernyataan positif yang paling tidak sesuai dengan realitas diberi skor terkecil, yaitu 1. Perlakuan sebaliknya diterapkan pada pernyataan negatif pada item pernyataan yang disajikan. Kriteria yang digunakan adalah "A" untuk selalu, "B" untuk sering, "C" untuk ragu-ragu, "D" untuk kadang-kadang, dan "E" untuk mewakili pilihan tidak pernah.
Tabel 3. Skor Instrumen Manajemen Operasi Laboratorium Komputer Dan Pemanfaatan Internet

\begin{tabular}{lccccc}
\hline \multirow{2}{*}{ Pernyataan } & \multicolumn{6}{c}{ Skor Alternatif } \\
\cline { 2 - 6 } & A & B & C & D & E \\
\hline Positif (+) & 5 & 4 & 3 & 2 & 1 \\
Negatif(-) & 1 & 2 & 3 & 4 & 5 \\
\hline
\end{tabular}

Variabel motivasi berprestasi menggunakan kriteria sangat setuju (5), setuju (4), ragu (3), tidak setuju (2), sangat tidak setuju (1). Skor yang diperoleh selanjutnya dikonversi menjadi data kualitatif skala lima (Likert scale) Sugiyono (2006, p.86). Sebelum melakukan uji hipotesis, data penelitian yang berupa data skala ordinal ditransformasikan terlebih dahulu ke- 
dalam bentuk data skala interval dengan menggunakan Methods Successive Interval (MSI) (Hidayat, 2005, p.55). Ketercapaian hasil belajar dilakukan dengan menghitung prosentase nilai tes objektif (Arikunto, 1999, p.228). Adapun skor instrumen motivasi berprestasi pada 5 skala likert tersaji pada Tabel 4.

Tabel 4. Skor Instrumen Motivasi Berprestasi Dan Pemanfaatan Internet

\begin{tabular}{llllll}
\hline \multirow{2}{*}{ Pernyataan } & \multicolumn{5}{c}{ Skor Alternatif } \\
\cline { 2 - 6 } & SS & S & N & TS & STS \\
\hline Positif (+) & 5 & 4 & 3 & 2 & 1 \\
Negatif (-) & 1 & 2 & 3 & 4 & 5 \\
\hline
\end{tabular}

Sumber: Sugiyono (2008, pp.87-88)

Pengolahan data dalam uji hipotesis dibagi dalam dua bagian yaitu menggunakan statistik regresi linier sederhana dan statistik regresi linier berganda. Sebelum melakukan uji hepotesis dengan menggunakan analisis regresi, maka persyaratan yang harus dipenuhi terhadap data yang akan dianalisis harus melalui uji normalitas, uji lineritas, dan uji homogenitas (Riduwan, 2008, p.184), juga uji multikolinearitas, autokorelasi, dan heteroskedastisitas (Sujarweni, 2007, pp.175-183). Taraf signifikansi yang ditetapkan sebesar 5\%.

\section{HASIL PENELITIAN DAN PEMBAHASAN}

\section{Deskripsi Data}

\section{Variabel manajemen operasi laboratorium komputer}

Hasil analisis data variabel manajemen laboratorium komputer menunjukkan bahwa skor terendah yang diperoleh sebesar 32 dan skor tertinggi adalah 91. Nilai rata-rata (mean) sebesar 71 . Sedangkan angka yang sering muncul (mode) adalah 65, nilai tengah (median) sebesar 72 dan standar deviasi sebesar 10,2074.

Penghitungan nilai mean ideal dan standar deviasi ideal terhadap skor yang diperoleh menghasilkan angka 60 untuk mean ideal dan 13,33 untuk standar deviasi ideal. Pada Lampiran 5 mendokumentasikan proses penghitungan nilai distribusi frekuensi variabel manajemen operasi laboratorium komputer yang dike- lompokkan kedalam 5 skala nilai. Pembagian interval skala nilai sebesar 1,2 yang mengacu pada tabel sigma. Hasil penghitungan distribusi frekuensi variabel manajemen operasi tersaji pada Tabel 5 .

Tabel 5. Distribusi Frekuensi Data Manajemen Operasi Laboratorium Komputer

\begin{tabular}{clc}
\hline Nilai & Kategori & Frekuensi \\
\hline 5 & Sangat Baik & $60 \%$ \\
4 & Baik & $0 \%$ \\
3 & Cukup & $36 \%$ \\
2 & Buruk & $3 \%$ \\
1 & Sangat Buruk & $1 \%$ \\
\hline
\end{tabular}

Berdasarkan presentasi data Tabel 13 dapat dideskripsikan bahwa manajemen laboratorium komputer pada SMK se-Kabupaten Bantul yang mempunyai jurusan RPL yang dikategorikan sangat baik sebesar $60 \%$, kategori cukup 36\%, kategori buruk sebesar 3\% dan kategori sangat buruk sebesar 1\%. Kesimpulan yang dapat diperoleh dari penyajian data di atas adalah proses manajemen operasi laboratorium komputer sudah dilakukan dengan baik di sekolah-sekolah yang mempunyai jurusan RPL se-Kabupaten Bantul dalam mendukung hasil belajar siswa.

Pengamatan terhadap proses manajemen operasi laboratorium komputer juga memperoleh kesimpulan yang senada dengan data persepsi siswa tentang pengelolaan manajemen operasi laboratorium komputer. Sejauh pengamatan selama penelitian, proses manajemen operasi laboratorium komputer yang dilakukan sudah baik, meskipun masih terkendala terhadap jumlah personil laboran. Setiap siswa dapat melaksanakan praktikum dengan baik, meskipun mereka menggunakan komputer jinjingnya masing-masing dikarenakan keterbatasan jumlah komputer yang tersedia kurang mencukupi. Dengan demikian maka ketercukupan rasio penggunaan komputer akan tercapai.

\section{Variabel Pemanfaatan Internet}

Hasil analisis data variabel pemanfaatan internet menunjukkan bahwa skor terendah yang diperoleh siswa sebesar 84 dan skor tertinggi adalah 171, nilai mean sebesar 123,6. Sedangkan angka mode adalah 131, nilai me- 
dian sebesar 125 dan standar deviasi sebesar 18,5199. Penghitungan nilai mean ideal dan standar deviasi ideal pada skor variabel pemanfaatan internet yang diperoleh menghasilkan angka 114 untuk mean ideal dan 25,333 untuk standar deviasi ideal. Pada Lampiran 5 mendokumentasikan proses penghitungan untuk mencari nilai distribusi frekuensi variabel pemanfaatan internet yang tersaji pada Tabel 6 .

Tabel 6. Distribusi Frekuensi Data Pemanfaatan Internet

\begin{tabular}{ccc}
\hline Nilai & Kategori & Frekuensi \\
\hline 5 & Sangat Baik & $0 \%$ \\
4 & Baik & $0 \%$ \\
3 & Cukup & $1 \%$ \\
2 & Buruk & $56 \%$ \\
1 & Sangat Buruk & $43 \%$ \\
\hline
\end{tabular}

Berdasarkan Tabel 6 dapat dideskripsikan bahwa pemanfaatan internet pada SMK yang mempunyai jurusan RPL dikategorikan sangat buruk sebesar $43 \%$, kategori buruk sebesar $56 \%$ dan kategori cukup sebesar 1\%. Kesimpulan yang dapat ditarik dari representasi data di atas adalah tidak ada satupun pemanfaatan internet yang dilakukan dengan optimal di seluruh SMK se-Kabupaten Bantul yang mempunyai jurusan RPL.

Hasil observasi pada saat penelitian juga menghasilkan kesimpulan yang senada dengan data persepsi siswa terhadap pemanfaatan internet di sekolah mereka masing-masing. Data observasi menunjukkan bahwa di sebagian besar sekolah yang diteliti mengalami kendala pada kapasitas lebar pita internet (bandwith). Kendala yang dirasakan oleh siswa adalah lambatnya koneksi internet. Dengan demikian antusiasme siswa dalam memanfaatkan internet sebagai salah satu media belajar dan sebagai sumber referensi juga rendah.

\section{Variabel Motivasi Berprestasi}

Hasil analisis data variabel motivasi berprestasi menunjukkan bahwa skor terendah yang diperoleh siswa sebesar 70,800 dan skor tertinggi adalah 139,205 . Nilai mean sebesar 119,120. Sedangkan angka mode adalah 115,8389 , nilai median sebesar 121,647 dan standar deviasi sebesar 12,61678. Penghitungan nilai mean ideal dan standar deviasi ideal terhadap skor yang diperoleh menghasilkan angka 106,0256 untuk mean ideal dan 24,00853 untuk standar deviasi ideal. Nilai distribusi frekuensi variabel pemanfaatan internet yang tersaji pada Tabel 7.

Tabel 7. Distribusi Frekuensi Data Motivasi Berprestasi

\begin{tabular}{ccc}
\hline Nilai & Kategori & Frekuensi \\
\hline 5 & Sangat Baik & $0 \%$ \\
4 & Baik & $56 \%$ \\
3 & Cukup & $39 \%$ \\
2 & Buruk & $6 \%$ \\
1 & Sangat Buruk & $0 \%$ \\
\hline
\end{tabular}

Berdasarkan Tabel 7 dapat dideskripsikan bahwa motivasi berprestasi siswa pada SMK se-Kabupaten Bantul yang mempunyai jurusan RPL mempunyai kategori baik sebesar 56\%, kategori cukup sebanyak 39\%, dan kategori buruk sebesar $6 \%$. Kesimpulan yang dapat diambil adalah meskipun tingkat motivasinya belum ada yang mencapai taraf sangat baik, dalam memperoleh hasil belajar yang tinggi siswa sudah termotivasi cukup baik.

\section{Variabel Hasil Belajar Siswa}

Hasil analisis data variabel motivasi berprestasi menunjukkan bahwa skor terendah yang diperoleh siswa sebesar 8 dan skor tertinggi adalah 70. Nilai mean sebesar 43. Angka mode adalah 43,24, nilai median sebesar 43,24 dan standar deviasi sebesar 11,86 . Penghitungan nilai mean ideal menghasilkan angka 50 dan 16,67 untuk standar deviasi ideal. Distribusi frekuensi variabel hasil belajar yang tersaji pada Tabel 8 .

Tabel 8. Distribusi Frekuensi Data Hasil Belajar

\begin{tabular}{ccc}
\hline Nilai & Kategori & Frekuensi \\
\hline 5 & Sangat Baik & $0 \%$ \\
4 & Baik & $11 \%$ \\
3 & Cukup & $52 \%$ \\
2 & Buruk & $34 \%$ \\
1 & Sangat Buruk & $2 \%$ \\
\hline
\end{tabular}

Berdasarkan Tabel 8 dapat dideskripsikan bahwa hasil belajar siswa pada SMK seKabupaten Bantul yang mempunyai jurusan RPL yang dikategorikan baik sebesar $11 \%$, kategori cukup sebanyak 52\%, kategori buruk 
sebesar 34\% dan kategori sangat buruk sebesar $2 \%$. Kesimpulan yang dapat disarikan dari penyajian data di atas adalah siswa belum memperoleh hasil belajar yang tinggi dikarenakan prosentase perolehan nilai yang masuk dalam kategori buruk relatif banyak, yaitu sebesar $34 \%$ dan pada kategori sangat buruk sebesar $2 \%$, sedangkan tidak ada satupun siswa yang memperoleh nilai hasil belajar pada kategori sangat baik.

Penilaian Acuan Norma (PAN) digunakan untuk proses penilaian dengan pertimbangan:
(1) perbedaan karakteristisk setiap sekolah, (2) ketersediaan sarana dan prasarana pembelajaran. Ketuntasan belajar yang dicapai oleh para siswa diperoleh sejumlah 103 (63\%) untuk kategori tuntas, sedangkan sisanya sejumlah 60 (37\%) dinyatakan tidak tuntas. Siswa yang dinyatakan tuntas adalah yang memperoleh nilai pada kategori cukup, baik dan sangat baik. Sedangkan siswa yang dinyatakan tidak tuntas pada kategori buruk dan sangat buruk. Penggunaan norma Visualisasi tingkat ketuntasan belajar tersaji pada Gambar 1.

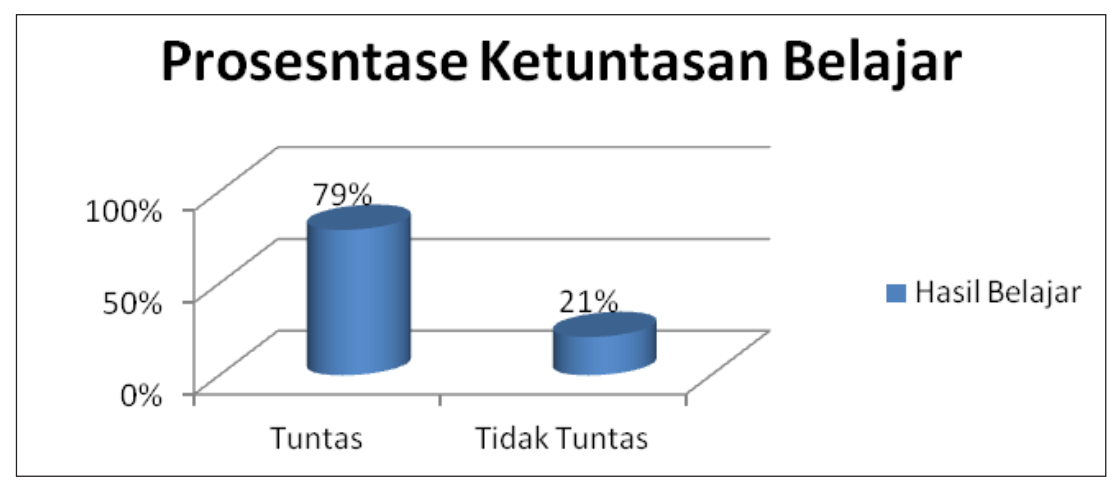

Gambar 1. Diagram Distribusi Frekuensi Data Ketuntasan Belajar Persyaratan Analisis

\section{Uji Normalitas}

Uji Normalitas data dapat dilihat dari hasil uji Kolmogorov-Smirnov (Sujarweni, 2007, p.45) pada data residualnya. Nilai hasil uji Kolmogorov-Smirnov yang tersaji pada Tabel 9 menunjukkan nilai Asymp. Sig (2-tiled) sebesar 0,621 pada taraf siginifikansi 5\%. Kriteria pengujian yang dilakukan adalah jika nilai Asymp. Sig $(0,621)>$ taraf signifikansi $(0,05)$, maka data terdistribusi normal, namun jika ditemui kondisi sebaliknya,dimana data Asymp. Sig $(2$-tiled $)<$ taraf signifikansi, maka data tidak terdistribusi normal. Melihat sajian data yang ada maka dapat ditarik kesimpulan bahwa pada penelitian data yang digunakan adalah normal dikarenakan nilai Asymp. Sig $>$ taraf signifikansi maka tidak signifikan, dengan kata lain data relatif sama dengan rata-rata sehingga disebut normal.

Tabel 9. Distribusi Frekuensi Data Hasil Belajar

\begin{tabular}{llr}
\hline & & Unstandardized Residual \\
\hline $\mathrm{N}$ & & 163 \\
Normal Parameters(a,b) & Mean &, 0000000 \\
& Std. Deviation & 8,44588046 \\
Most Extreme Differences & Absolute &, 059 \\
& Positive &, 059 \\
& Negative &,- 053 \\
Kolmogorov-Smirnov Z & &, 754 \\
Asymp. Sig. (2-tailed) & &, 621 \\
\hline
\end{tabular}


Uji normalitas pada penelitian ini juga mengamati pola histogram yang membandingkan data observasi dengan distribusi yang mendekati diistribusi normal. Histogram normal probability plots pada uji normalitas penelitian ini tersaji pada Gambar 2. Histogram normal probability plots menunjukkan titiktitik menyebar berhimpitan disekitar garis diagonal. Hal ini menunjukkan bahwa residual terdistribusi secara normal.

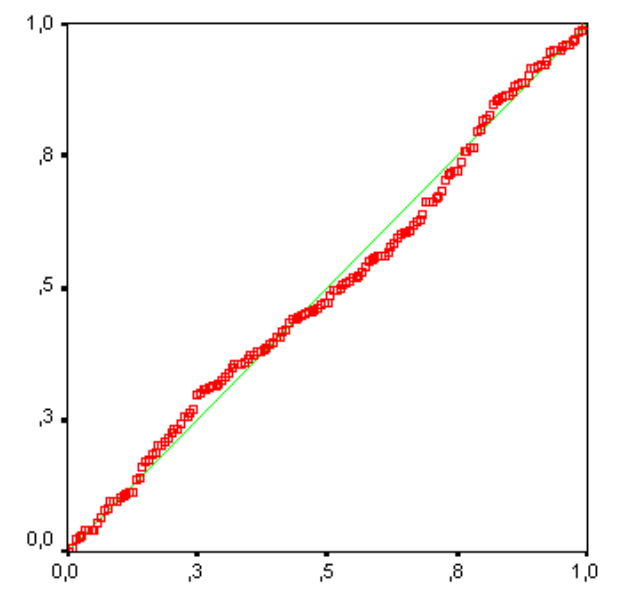

Gambar 2. Grafik Normal Probability Plots

\section{Uji Linieritas}

Uji linieritas digunakan untuk melihat apakah spesifikasi model yang digunakan benar atau salah. Melalui uji linieritas juga akan diketahui model empiris yang sebaiknya digunakan, apakah linier, kuadran, atau kubik.

Uji linieritas dapat dilakukan mencermati kurva dimana model dikatakan linier jika plot antara nilai residual terstandarisasi dengan nilai prediksi terstandarisasi tidak membentuk pola tertentu (acak). Selain dengan mencermati kurva, uji linieritas juga dilakukan dengan mencermati lajur liniarity. Ketentuan pengambilan keputusan yang digunakan adalah jika nilai signifikansi pada lajur liniarity $<$ taraf signifikansi yang digunakan, maka disimpulkan hubungan variabel bebas dengan variabel terikat adalah linier. Sebaliknya, jika nilai lajur liniarity $>$ taraf signifikansi yang digunakan, maka variabel bebas dan variabel terikan adalah tidak linier. Rangkuman dari nilai lajur liniarity pada masing-masing variabel terangkum pada Tabel 10.

Tabel 10. Rangkuman Nilai Sig Lajur Liniarity

\begin{tabular}{lcl}
\hline Variabel & $\begin{array}{l}\text { Nilai sig lajur } \\
\text { Liniarity }\end{array}$ & \multicolumn{1}{c}{ Kesimpulan } \\
\hline SKORY * Manajemen Operasi Lb. Komputer & $0,000<0,05$ & Hubungan linier signifikan \\
SKORY * Pemanfaatan Internet & $0,000<0,05$ & Hubungan linier signifikan \\
SKORY * Motivasi Berprestasi & $0,002<0,05$ & Hubungan linier signifikan \\
\hline
\end{tabular}

Hasil pencermatan data uji linieritas baik melalui pencermatan kurva maupun dari nilai lajur liniarity menunjukkan bahwa data yang digunakan pada penelitian ini antara variabel bebas dan variabel terikat adalah linier. Pencermatan kurva menunjukkan plot yang tersebar secara acak pada masing-masing variabel manajemen operasi laboratorium, pemanfaatan internet dan motivasi berprestasi. Sedangkan pencermatan melalui lajur liniarity menunjukkan bahwa masing-masing nilai liniarity pada variabel manajemen operasi laboratorium, pemanfaatan internet dan motivasi berprestasi mempunyai nilai yang lebih kecil dari taraf signifikan yang digunakan pada penelitian ini. Uji Multikolinearitas
Pengambilan keputusan atas hasil uji yang dilakukan adalah jika nilai $V I F$ diantara 1-10 maka tidak terjadi multikolinearitas (Sujarweni, 2007, p.178). Akibat terjadinya multikolinearitas pada model regresi adalah kesalahan standar estimasi akan cenderung meningkat dengan bertambahnya variabel bebas, tingkat signifikansi untuk menolak hipotesis nol akan semakin besar, dan probabilitas untuk menerima hipotesis yang salah (kesalahan $\beta)$ juga akan semakin besar sehingga model regresi yang diperoleh tidak sahih (valid) untuk menaksir nilai variabel bebas (Algifari, 2013, p.84). Rangkuman hasil uji multikolinearitas tersaji pada Tabel 11. 
Tabel 11. Hasil Uji Multikolinearitas

\begin{tabular}{llccc}
\hline \multirow{2}{*}{ Model } & Sig. & \multicolumn{2}{c}{ Collinearity Statistics } \\
\cline { 5 - 5 } & &, 000 & Tolerance & VIF \\
\hline 1 & (Constant) &, 000 &, 687 & 1,455 \\
& Manajemen Operasi Lb. Komputer &, 000 &, 642 & 1,558 \\
& Pemanfaatan Internet &, 001 &, 800 & 1,249 \\
\hline
\end{tabular}

Hasil uji multikolinearitas pada variabel manajemen operasi laboratorium komputer mempunyai nilai tolerance sebesar 0,687 dan nilai $V I F$ sebesar 1,455. Variabel pemanfaatan internet mempunyai nilai tolerance sebesar 0,642 dan nilai $V I F$ sebesar 1,558. Variabel motivasi berprestasi mempunyai nilai tolerance sebesar 0,800 dan nilai VIF sebesar 1,249 . Seluruh variabel bebas mempunyai nilai tolerance lebih besar dari $0,1(10 \%)$ serta nilai VIF diantara $1 \mathrm{~s} / \mathrm{d} 10$. Hasil pencermatan uji multikolinearitas terhadap seluruh variabel yang ada dapat disimpulkan bahwa tidak terjadi multikolinearitas terhadap variabel-variabel bebas yang digunakan dalam penelitin ini. Hasil Uji Multikolinearitas.

\section{Uji Autokorelasi}

Pada penelitian ini, uji autokorelasi dilakukan menggunakan uji Durbin-Watson dimana kriteria pengambilan keputusannya tersaji pada Tabel 12 yang menentukan kesimpulan bahwa hanya nilai 1,66 - 2,34 pada hasil uji DurbinWatson yang disimpulkan tidak ada autokorelasi. Hasil uji autokorelasi menunjukkan nilai Durbin-Watson sebesar 1,855. Nilai DurbinWatson tersebut berada diantara 1,66 sampai dengan 2,34 yang berarti bahwa tidak terjadi autokorelasi antar variabel dalam model regresi yang digunakan pada penelitian ini. Adapun rangkuman hasil uji autokorelasi menggunakan Durbin-Watson tersaji pada Tabel 12.

Tabel 12. Hasil Uji Autokorelasi Menggunakan Durbin-Watson

\begin{tabular}{cccc}
\hline Model & R & R Square & Durbin-Watson \\
\hline 1 &, $702(a)$ &, 493 & 1,855 \\
\hline
\end{tabular}

\section{Uji Heteroskedastisitas}

Hasil uji heteroskedastisitas variabel manajemen operasi laboratorium komputer mempunyai nilai Sig sebesar 0,820, variabel pemanfaatan internet sebesar 0,229 dan variabel motivasi berprestasi sebesar 0,545. Datadata di atas dapat ditarik kesimpulan bahwa varian variabel dalam model regresi yang digunakan tidak mengalami heteroskedastisitas. Rangkuman atas hasil uji heteroskedastisitas tersaji pada Tabel 13 berikut ini.

Tabel 13. Hasil Uji Multikolinearitas

\begin{tabular}{llc}
\hline Model & \multicolumn{1}{c}{ t } & Sig. \\
\hline (Constant) &,- 284 &, 777 \\
Manajemen Operasi Lb. Komputer &, 227 &, 820 \\
Pemanfaatan Internet & 1,207 &, 229 \\
Motivasi Berprestasi &, 607 &, 545 \\
\hline
\end{tabular}

\section{Analisis Data}

\section{Uji Hipotesis pertama}

Hipotesis pertama, manajemen operasi laboratorium komputer berkontribusi positif dan signifikan terhadap hasil belajar siswa SMK jurusan RPL se-Kabupaten Bantul. Hipotesis ini digunakan untuk mengetahui kontribusi manajemen operasi laboratorium komputer terhadap hasil belajar. Rangkuman analisis uji regresi sederhana antara variabel manajemen operasi laboratorium komputer dan hasil belajar siswa tersaji pada Tabel 14 dan Tabel 15.

Merujuk Tabel 15 menunjukkan bahwa koefisien regresi manajemen operasi laboratorium komputer terhadap hasil belajar siswa sebesar 0,701 pada tingkat signifikansi yang digunakan adalah $5 \%$, nilai probabilitasnya 0,000 dan nilai konstantanya sebesar $-6,683$.

Nilai probabilitas yang tertera pada kolom sig bernilai 0,000 . Makna nilai $\mathrm{p}(0,000)<\alpha$ $(0,05)$ adalah kontribusi manajemen operasi laboratorium komputer terhadap hasil belajar siswa signifikan. Kesimpulan yang dapat diambil adalah manajemen operasi laboratorium 
Tabel 14. Koefisien Regresi Manajemen Operasi Lab. Komputer dan Hasil Belajar

\begin{tabular}{|c|c|c|c|c|c|c|}
\hline & \multirow[t]{2}{*}{ Model } & \multicolumn{2}{|c|}{$\begin{array}{l}\text { Unstandardized } \\
\text { Coefficients }\end{array}$} & \multirow{2}{*}{$\begin{array}{c}\begin{array}{c}\text { Standardized } \\
\text { Coefficients }\end{array} \\
\text { Beta } \\
\end{array}$} & \multirow[t]{2}{*}{$\mathbf{t}$} & \multirow[t]{2}{*}{ Sig. } \\
\hline & & $\mathbf{B}$ & Std. Error & & & \\
\hline \multirow[t]{2}{*}{1} & (Constant) & $-6,683$ & 5,251 & & $-1,273$ & 205, \\
\hline & Manajemen Operasi Lb. Komputer &, 701 &, 073 & ,603 & 9,593 &, 000 \\
\hline
\end{tabular}

Tabel 15. Model Summary Manajemen Operasi Lab. Komputer dan Hasil Belajar

\begin{tabular}{ccccc}
\hline Model & R & R Square & Adjusted R Square & Std. Error of the Estimate \\
\hline 1 &, $603($ a) &, 364 &, 360 & 9,49319 \\
\hline
\end{tabular}

Tabel 16. Koefisien Regresi Pemanfaatan Internet dan Hasil Belajar

\begin{tabular}{|c|c|c|c|c|c|c|}
\hline & \multirow[t]{2}{*}{ Model } & \multicolumn{2}{|c|}{$\begin{array}{c}\text { Unstandardized } \\
\text { Coefficients }\end{array}$} & \multirow{2}{*}{$\begin{array}{c}\begin{array}{c}\text { Standardized } \\
\text { Coefficients }\end{array} \\
\text { Beta }\end{array}$} & \multirow[t]{2}{*}{$\mathbf{t}$} & \multirow[t]{2}{*}{ Sig. } \\
\hline & & B & Std. Error & & & \\
\hline \multirow[t]{2}{*}{1} & (Constant) & $-2,749$ & 5,137 & &,- 535 & ,593 \\
\hline & Pemanfaatan Internet & ,372 &, 041 &, 580 & 9,039 &, 000 \\
\hline
\end{tabular}

Tabel 17. Model Summary Pemanfaatan Internet dan Hasil Belajar

\begin{tabular}{ccccc}
\hline Model & R & R Square & Adjusted R Square & Std. Error of the Estimate \\
\hline 1 &, $580($ a) &, 337 &, 333 & 9,69287 \\
\hline
\end{tabular}

komputer berkontribusi positif dan signifikan terhadap hasil belajar siswa. Dengan demikian, hipotesis $\mathrm{H}_{1}$ yang menyatakan manajemen operasi laboratorium komputer berkontribusi positif dan signifikan terhadap hasil belajar siswa SMK jurusan RPL se-Kabupaten Bantul terbukti. Sedangkan $\mathrm{H}_{0}$ yang menyatakan manajemen operasi laboratorium komputer tidak berkontribusi positif dan signifikan terhadap hasil belajar siswa SMK jurusan RPL se-Kabupaten Bantul ditolak.

Korelasi dan kontribusi manajemen operasi laboratorium komputer terhadap hasil belajar siswa diketahui dari besarnya nilai $\mathrm{R}$ (koefisien korelasi) dan nilai R Square (koefisien determinasi) di Tabel 15. Mengacu data pada Tabel 15 diketahui bahwa nilai $\mathrm{R}$ (koefisien korelasi) sebesar 0,603, yang bermakna bahwa terdapat tingkat hubungan yang kuat antara manajemen operasi laboratorium komputer dan hasil belajar siswa sebesar 0,603.

Nilai R Square (koefisien determinasi) sebesar 0,364 yang bermakna bahwa kontribusi manajemen operasi laboratorium komputer terhadap hasil belajar sebesar 36,4\%, sedangkan sisanya sebesar $63,6 \%$ dipengaruhi oleh variabel yang lainnya. Pemaknaan lain terhadap nilai koefisien determinasi (R Square) adalah model regresi tersebut dapat menerangkan varian independen dalam menjelaskan variasi variabel dependen dengan nilai goodness-fit sebesar $63,6 \%$.

\section{Uji Hipotesis Kedua}

Hipotesis kedua, pemanfaatan internet berkontribusi positif dan signifikan terhadap hasil belajar siswa SMK jurusan RPL se-Kabupaten Bantul. Rangkuman analisis uji regresi sederhana antara variabel pemanfaatan internet dan hasil belajar siswa tersaji pada Tabel 16 dan Tabel 17.

Hasil analisis data diketahui bahwa koefisien regresi pemanfaatan internet terhadap hasil belajar siswa sebesar 0,372 pada tingkat signifikansi yang digunakan adalah $5 \%$, nilai probabilitasnya 0,000 dan nilai konstantanya sebesar $-2,749$. Makna nilai $\mathrm{p}(0,000)<\alpha$ $(0,05)$ adalah kontribusi pemanfaatan internet terhadap hasil belajar siswa signifikan. Kesimpulan yang dapat diambil adalah pemanfaatan 
Tabel 18. Koefisien Regresi Motivasi Berprestasi dan Hasil Belajar

\begin{tabular}{llccccc}
\hline \multirow{2}{*}{ Model } & \multicolumn{2}{c}{$\begin{array}{c}\text { Unstandardized } \\
\text { Coefficients }\end{array}$} & $\begin{array}{c}\text { Standardized } \\
\text { Coefficients }\end{array}$ & \multirow{2}{*}{ Sig. } \\
\cline { 3 - 5 } & B & Std. Error & Beta & & \\
\hline \multirow{2}{*}{1} & (Constant) & $-9,617$ & 7,829 & & $-1,228$ &, 221 \\
& Manajemen Operasi Lb. Komputer &, 443 &, 065 &, 471 & 6,781 &, 000 \\
\hline
\end{tabular}

Tabel 19. Model Summary Motivasi Berprestasi dan Hasil Belajar

\begin{tabular}{ccccc}
\hline Model & R & R Square & Adjusted R Square & Std. Error of the Estimate \\
\hline 1 &, $471(\mathrm{a})$ &, 222 &, 217 & 10,49598 \\
\hline
\end{tabular}

internet berkontribusi positif dan signifikan terhadap hasil belajar siswa. Dengan demikian, hipotesis kedua yang menyatakan pemanfaatan internet berkontribusi positif dan signifikan terhadap hasil belajar siswa SMK jurusan RPL se-Kabupaten Bantul terbukti.

Korelasi dan kontribusi pemanfaatan internet terhadap hasil belajar siswa dapat diketahui dari besarnya nilai (koefisien korelasi) $\mathrm{R}$ dan nilai R Square (koefisien determinasi) di Tabel 17 diketahui nilai $\mathrm{R}$ sebesar 0,580 . Pemaknaan lain terhadap nilai $\mathrm{R}$ sebesar 0,580 adalah terdapat hubungan yang cukup kuat antara pemanfaatan internet dengan hasil belajar siswa.

Nilai R Square sebesar 0,337. Makna dari angka R Square sebesar 0,337 tersebut adalah kontribusi pemanfaatan internet terhadap hasil belajar sebesar 33,7\%, sedangkan sisanya sebesar $66,3 \%$ dipengaruhi oleh variabel yang lainnya. Pemaknaan lain terhadap nilai koefisien determinasi (R Square) adalah model regresi tersebut dapat menerangkan varian independen dalam menjelaskan variasi variabel dependen dengan nilai goodness-fit sebesar 33,7\%.

\section{Uji Hipotesis Ketiga}

Hipotesis ketiga, motivasi berprestasi berkontribusi positif dan signifikan terhadap hasil belajar siswa SMK jurusan RPL se-Kabupaten Bantul. Hipotesis ini digunakan untuk mengetahui kontribusi motivasi berprestasi terhadap hasil belajar siswa. Rangkuman analisis uji regresi sederhana antara variabel motivasi berprestasi dan hasil belajar siswa tersaji pada Tabel 18 dan Tabel 19.
Hasil analisis data diketahui bahwa koefisien regresi motivasi berprestasi terhadap hasil belajar siswa yang tertera pada Tabel 18 sebesar 0,443 . Tingkat signifikansi yang digunakan adalah $5 \%$ dengan nilai probabilitasnya 0,000 dan nilai konstantanya sebesar -9,617. Makna nilai $\mathrm{p}(0,000)<\alpha(0,05)$ adalah kontribusi motivasi berprestasi terhadap hasil belajar siswa signifikan. Kesimpulan yang dapat diambil adalah motivasi berprestasi berkontribusi positif dan signifikan terhadap hasil belajar siswa. Dengan demikian, hipotesis ketiga yang menyatakan motivasi berprestasi berkontribusi positif dan signifikan terhadap hasil belajar siswa SMK jurusan RPL se-Kabupaten Bantul terbukti.

Korelasi dan kontribusi motivasi berprestasi terhadap hasil belajar siswa dapat diketahui dari besarnya nilai $\mathrm{R}$ (koefisien korelasi) dan nilai R Square (koefisien determninasi) di Tabel 19 diketahui nilai $R$ sebesar 0,471 yang bermakna bahwa terdapat hubungan yang cukup kuat antara motivasi berprestasi dengan hasil belajar siswa sebesar 0,471. Nilai R Square (koefisien determinasi) sebesar 0,222. Makna dari angka R Square sebesar 0,222 tersebut adalah kontribusi motivasi berprestasi terhadap hasil belajar sebesar 22,2\%, sedangkan sisanya sebesar $77,8 \%$ dipengaruhi oleh variabel yang lainnya. Pemaknaan lain terhadap nilai koefisien determinasi (R Square) adalah model regresi tersebut dapat menerangkan varian independen dalam menjelaskan variasi variabel dependen dengan nilai goodness-fit sebesar $22,2 \%$. 
Tabel 20. Koefisien Regresi Manajemen Laboratorium Komputer, Pemanfaatan Internet dan Motivasi Berprestasi Terhadap Hasil Belajar

\begin{tabular}{|c|c|c|c|c|c|c|}
\hline & \multirow[t]{2}{*}{ Model } & \multicolumn{2}{|c|}{$\begin{array}{c}\text { Unstandardized } \\
\text { Coefficients }\end{array}$} & \multirow{2}{*}{$\begin{array}{c}\begin{array}{c}\text { Standardized } \\
\text { Coefficients }\end{array} \\
\text { Beta }\end{array}$} & \multirow[t]{2}{*}{$\mathbf{t}$} & \multirow[t]{2}{*}{ Sig. } \\
\hline & & B & Std. Error & & & \\
\hline \multirow[t]{4}{*}{1} & (Constant) & $-34,811$ & 6,932 & & $-5,022$ &, 000 \\
\hline & Manajemen Operasi Lb. Komputer & ,431 & ,079 & ,371 & 5,449 &, 000 \\
\hline & Pemanfaatan Internet &, 182 & ,045 & 285 & 4,041 &, 000 \\
\hline & Motivasi Berprestasi & ,208 & 059 & 221 & 3,504 & 001 \\
\hline
\end{tabular}

Tabel 21. Model Summary Manajemen Operasi Laboratorium Komputer, Pemanfaatan Internet dan Motivasi Berprestasi Terhadap Hasil Belajar

\begin{tabular}{ccccc}
\hline Model & R & R Square & Adjusted R Square & Std. Error of the Estimate \\
\hline 1 &, $702(a)$ &, 493 &, 484 & 8,52519 \\
\hline
\end{tabular}

\section{Uji Hipotesis Keempat}

Hipotesis keempat, manajemen operasi laboratorium komputer, pemanfaatan internet dan motivasi berprestasi secara bersama-sama berkontribusi positif dan signifikan terhadap hasil belajar siswa SMK jurusan RPL se-Kabupaten Bantul. Hasil analisis data diketahui bahwa nilai koefisien manajemen operasi laboratorium komputer $\left(\mathrm{X}_{1}\right)$ sebesar 0,431 , nilai koefisien pemanfaatan internet $\left(\mathrm{X}_{2}\right)$ sebesar 0,182 dan nilai koefisien motivasi berprestasi $\left(\mathrm{X}_{3}\right)$ sebesar 0,208 dengan nilai positif pada masing-masing variabel. Makna dari nilai koefisien positif adalah akan terjadi kenaikan hasil belajar searah dengan kenaikan manajemen operasi laboratorium komputer, pemanfaatan internet dan motivasi berprestasi sebesar satu satuan.

Nilai probabilitas yang tertera pada kolom sig di Tabel 20 untuk variabel manajemen operasi laboratorium komputer sebesar 0,000 , pemanfaatan internet sebesar 0,000 dan motivasi berprestasi bernilai 0,001 . Seluruh nilai probabilitas masing-masing variabel bebas lebih kecil dari taraf signifikansi yang digunakan $(0,05)$. Dengan kata lain jika nilai $\mathrm{p}<\alpha$ maka kontribusi manajemen operasi laboratorium komputer, pemanfaatan internet dan motivasi berprestasi secara bersama-sama terhadap hasil belajar siswa signifikan.

Kesimpulan yang dapat diambil adalah variabel manajemen operasi laboratorium komputer, pemanfaatan internet dan motivasi berprestasi secara bersama-sama berkontribusi positif dan signifikan terhadap hasil belajar siswa. Dengan demikian, hipotesis keempat yang menyatakan manajemen operasi laboratorium komputer, pemanfaatan internet dan motivasi berprestasi secara bersama-sama berkontribusi positif dan signifikan terhadap hasil belajar siswa SMK jurusan RPL se-Kabupaten Bantul terbukti.

Mengacu pada Tabel 21 diketahui nilai $\mathrm{R}$ sebesar 0,702. Representasi dari nilai $\mathrm{R}$ sebesar 0,702 adalah terdapat tingkat hubungan yang kuat antara manajemen operasi laboratorium komputer, pemanfaatan internet dan motivasi berprestasi secara bersama-sama terhadap hasil belajar siswa. Nilai R Square sebesar 0,493. Makna dari angka R Square sebesar 0,493 tersebut adalah kontribusi variabel manajemen operasi laboratorium komputer, pemanfaatan internet dan motivasi berprestasi terhadap hasil belajar sebesar 49,3\%, sedangkan sisanya sebesar $50,7 \%$ dipengaruhi oleh variabel lain yang tidak diteliti dalam penelitian ini.

\section{Pembahasan}

Kontribusi manajemen operasi laboratorium komputer terhadap hasil belajar siswa di jurusan RPL SMK se-Kabupaten Bantul

Pengelolaan laboratorium yang baik mencakup 4 hal yaitu: (1) perencanaan, (2) pengelolaan, (3) perawatan, dan (4) keberlanjutan. 
Perencanaan yang telah dilakukan oleh masing-masing pengelola laboratorium komputer pada umunya berkaitan dengan penyusunan desain ruangan laboratorium, struktur organisasi, tata tertib, serta lokasi laboratorium. Sebagian responden menilai sangat baik dalam hal perencanaan manajemen operasi laboratorium komputer.

Pengelolaan yang dilakukan adalah usaha untuk menjaga agar laboratorium dapat berfungsi dan dapat digunakan sesuai dengan tujuan yang telah direncanakan. Kumar dan Suresh (2009, p.7) menyatakan bahwa seorang laboran yang memberikan operasi pelayanan harus bisa melakukan proses konversi yang mencakup hasil layanan yang berupa perbuatan, kinerja, dan upaya, sehingga pengelolaan sumber daya dapat secara langsung menghasilkan sebuah produk atau sebuah layanan jasa (Rowbotham, Galloway, \& Azhashemi, 2007, p.2). Mengacu pada Permendiknas Nomor 24 Tahun 2007, standar ruang laboratorium adalah $30 \mathrm{~m}^{2}$ dan lebar $5 \mathrm{~m}$ yang digunakan untuk 15 siswa dengan rasio minimum luas ruang laboratorium komputer adalah $2 \mathrm{~m}^{2} /$ peserta didik. Sedangkan kenyataan di lapangan yang ditemukan adalah rasio luas laboratorium komputer kurang dari $2 \mathrm{~m}^{2}$.

Pemenuhan atas ketersediaan laboratorium sangat penting untuk segera direalisasikan karena menurut Permendiknas Nomor 24 Tahun 2007, keberadaan laboratorium komputer sangat strategis, yaitu berfungsi sebagai tempat mengembangkan keterampilan dalam bidang teknologi informasi dan komunikasi, selain itu pasal 28 dalam Peraturan Pemerintah Nomor 5 Tahun 1980, bahwa fungsi laboratorium sebagai penunjang pelaksanaan tugas pokok jurusan sesuai dengan ketentuan bidang yang bersangkutan. Data hasil penelitian menunjukkan bahwa semakin tinggi manajemen operasi laboratorium komputer, maka akan semakin besar hasil belajar yang diperoleh. Menurut Kumar dan Suresh (2009, pp.11-13), bahwa salah satu tujuan manajemen operasi adalah layanan pelanggan melalui memanfaatkan sumber daya untuk memenuhi kepuasan pelanggan, sehingga pelayanan pelanggan adalah tujuan utama dari manajemen operasi dan pemanfaatan sumber daya secara efektif melalui penggunaan yang efisien. Dengan demikian, manajemen operasi laboratorium komputer yang dilakukan dengan baik akan memenuhi kepuasan para siswa dalam hal pelayanan yang berimbas pada peningkatan hasil belajarnya melalui penggunaan sumberdaya yang ada di laboratorium secara efektif dan efisien.

\section{Kontribusi pemanfaatan internet terhadap hasil belajar siswa di jurusan RPL SMK se- Kabupaten Bantul}

Data hasil pengamatan dan wawancara pada saat penelitian terungkap hanya 2 sekolah yang memperoleh akses internet secara baik, yaitu di SMK Muhammadiyah 1 Bantul dan di SMK Muhammadiyah Bambanglipuro sedangkan di sekolah lain memperoleh akses internet yang relatif lebih buruk. Kategori akses internet yang baik jika pada sebuah komputer dapat memperoleh kapasitas bandwith setara dengan 14.4 Kbps (kilo bit per second) (Horton \& Horton, 2003, p.91).

Pencermatan terhadap pemanfaatan internet untuk digunakan sebagai media pembelajaran baik melalui e-learning berbasis web maupun optimalisasi penggunaan email juga masih rendah yang disebabkan beberapa faktor, diantaranya adalah kemampuan guru dalam mengoperasikan internet yang belum merata, terkedala dengan kecepatan akses jaringan internet, dan pertimbangan lainnya. Untuk itu, berbagai kendala yang dihadapi para pendidik dalam pemanfaatan internet perlu segera di atasi, diantaranya adalah melalui pendalaman tentang bagaimana dapat belajar dan mengajar dilingkungan e-learning secara efektif.

Langkah pertama dalam berlatih belajar dan mengajar di lingkungan e-learning adalah melalui menulis dan membaca materi di layar komputer. Menurut Katy (2004, pp.125-127), membaca dari layar komputer lebih lambat $25 \%$ daripada membaca melalui kertas. Oleh karena itu, membaca di layar komputer dilakukan dengan cara scanning dari kata perkata dengan beberapa alasan: (1) resolusi layar biasanya $10 \%$ lebih kecil terhadap ukuran yang di kertas sebenarnya; (2) ukuran layar biasanya lebih kecil dari ukuran cetakan kertas sebenarnya; (3) membaca pada layar monitor yang merupakan sumber cahaya embuat mata beker- 
ja lebih keras; (4) para pembaca elektronik (e-reader) lebih aktif dari pada para pembaca konvensional, biasanya pembaca e-reader lebih sering melakukan hal-hal yang bersifat interaktif pada saat membaca.

Keberadaan website sekolah seyogyanya dimanfaatkan secara optimal. Diantaranya adalah melalui pembuatan media ajar yang diunggah ke laman website sekolah tersebut. Selain itu, optimalisasi email sekolah selain digunakan sebagai media komunikasi berbasis surat elektronik, juga dapat digunakan untuk mengirim dan menampung hasil karya siswa yang telah ditugaskan oleh guru. Hal tersebut akan lebih efektif jika setiap guru diberikan kuota email pada webmail sekolah, sehingga peran aktif guru akan semakin maksimal dalam memanfaatkan fasilitas internet tersebut.

Data penelitian mengungkapkan bahwa semakin tinggi pemanfaatan internet, maka akan semakin besar hasil belajar yang diperoleh sehingga sesuai dengan pendapat Milss (2006, p.3), bahwa pemanfaatan internet dapat meningkatkan kemampuan kognitif melalui penelitian dan representasi dari pengetahuan.

\section{Kontribusi motivasi berprestasi terhadap hasil belajar siswa di jurusan RPL SMK se- Kabupaten Bantul}

Penelitian ini mengungkapkan bahwa bahwa semakin tinggi motivasi berprestasi, maka akan semakin besar hasil belajar yang diperoleh. Sesuai dengan hasil penelitian Barakatu (2007, p.48), bahwa guru mempunyai peranan besar dalam mengembangkan self efficacy siswa yang dituangkan dalam prosedur instruksional.

Penerapan prosedur instruksional ini secara teliti dapat mengembangkan hasil prestasi pembelajaran dan mendorong motivasi berprestasi untuk kegiatan-kegiatan belajar berikutnya. Sesuai dengan yang diungkapkan oleh Alderman (2004, pp.7-9), bahwa strategi model pembelajaran yang paling tepat adalah model pembelajaran sebaya. Hal tersebut dikarenakan pada model pembelajaran tindkat sebaya sangat efektif untuk membantu siswa dalam memotivasi dirinya agar lebih mampu.

Kontribusi manajemen operasi laboratorium komputer, pemanfaatan internet dan motivasi berprestasi terhadap hasil belajar siswa jurusan RPL SMK se-Kabupaten Bantul

Hasil penelitian menunjukkan bahwa manajemen operasi laboratorium komputer berkontribusi positif terhadap hasil belajar siswa. Tujuan utama proses pendidikan adalah mempersiapkan peserta didik dalam menguasai dan ahli dibidang yang mereka pelajari. Penguasaan atas materi yang telah diperoleh ditandai dengan nilai hasil belajar yang baik. Tujuan melakukan manajemen operasi laboratorium adalah layanan pelanggan dan pemanfaatan sumberdaya secara efektif dan efisien, sehingga dengan melakukan manajemen operasi laboratorium secara baik, maka akan meningkatkan hasil belajar siswa. Hal tersebut sejalan dengan teori yang diungkapkan oleh Monks dalam Kumar dan Suresh (2009, p.11).

Pemanfaatan internet mempunyai kontribusi positif terhadap hasil belajar siswa jurusan RPL se-Kabupaten Bantul. Besaran kontribusi pemanfaatan internet terhadap hasil belajar siswa adalah 4,041. Berbagai fasilitas tersedia dalam internet, mulai dari berselancar, percakapan berbasis texting (Chatting), video converence, percakapan berbasis suara (VOIP), persuratan elektronik, sosial media, dan sebagainya. Dengan berbagai fasilitas yang disediakan oleh internet, maka pemanfaatan internet akan mendorong perolehan informasi dalam pemecahan sebuah masalah dan dapat memunculkan ide baru, mendukung motivasi guru dan murid untuk belajar, serta menumbuhkan interaksi antara murid ke murid dan guru ke murid (Mills, 2006, p.2).

Motivasi berprestasi mempunyai kontribusi positif terhadap hasil belajar siswa di jurusan RPL pada SMK se-Kabupaten Bantul. Besaran kontribusi motivasi berprestasi terhadap hasil belajar siswa adalah 4,504. Motivasi berprestasi dipengaruhi oleh tingkat kepercayaan diri, kemampuan kognitif, dan variabel emosional. Variabel emosional dan kognitif yang dimaksud adalah percaya diri dan keyakinan diri atas kompetensi yang telah dia kuasai melalui berbagai pendekatan yang dapat meningkatkan motivasi berprestasi (Alderman, 2004, pp.18-19). Dengan demikian, semakin tinggi mitovasi siswa, maka akan semakin baik pula nilai hasil belajar siswa. 


\section{SIMPULAN DAN SARAN}

\section{Simpulan}

Kesimpulan yang dapat diambil berdasarkan hasil penelitian yang telah dilakukan adalah sebagai berikut: (1) Manajemen operasi laboratorium komputer berkontribusi positif dan signifikan terhadap hasil belajar siswa SMK jurusan RPL se-Kabupaten Bantul. Nilai $p(0,000)<$ nilai $\alpha(0,05)$, terdapat tingkat hubungan yang kuat dan searah antara manajemen operasi laboratorium komputer dan hasil belajar siswa sebesar 0,603. Besar kontribusi manajemen operasi laboratorium komputer terhadap hasil belajar adalah $36,4 \%$, sedangkan sisanya sebanyak $63,6 \%$ dipengaruhi oleh variabel yang lainnya; (2) Pemanfaatan internet berkontribusi positif dan signifikan terhadap hasil belajar siswa SMK jurusan RPL seKabupaten Bantul. Nilai p $(0,000)<\alpha(0,05)$. Kontribusi pemanfaatan internet terhadap hasil belajar siswa sebesar 33,7\% sedangkan sisanya sebesar $66,3 \%$ dipengaruhi oleh variabel lain; (3) Motivasi berprestasi berkontribusi positif dan signifikan terhadap hasil belajar siswa SMK jurusan RPL se-Kabupaten Bantul ( $\mathrm{r}_{\mathrm{xly}}$ $=0,471 ; \mathrm{p}<0,05)$. Kontribusi motivasi berprestasi terhadap hasil belajar sebesar $22,2 \%$, sedangkan sisanya sebesar $77,8 \%$ dipengaruhi oleh variabel yang lainnya. Tingkat hubungan antara variabel motivasi berprestasi dan hasil belajar siswa cukup kuat, sebesar 0,471 ; (4) Manajemen operasi laboratorium komputer, pemanfaatan internet dan motivasi berprestasi secara bersama-sama berkontribusi positif dan signifikan terhadap hasil belajar siswa SMK jurusan RPL se-Kabupaten Bantul $\left(\mathrm{r}_{\mathrm{x} 11 \mathrm{y} ; \mathrm{x} 21 \mathrm{y} ; \mathrm{x} 3 \mathrm{y} \text {. }}\right.$ $=0,702 ; \mathrm{p}<0,05)$. Besar kontribusi manajemen operasi laboratorium, pemanfaatan internet dan motivasi berprestasi secara bersamasama terhadap hasil belajar sebesar 49,3\%, sedangkan sisanya sebesar $50,7 \%$ dipengaruhi variabel lain yang tidak diteliti pada penelitian ini. Tingkat hubungan yang terjadi secara simultan antara variabel manajemen operasi laboratorium komputer, pemanfaatan internet, dan motivasi berprestasi terhadap hasil belajar siswa SMK jurusan RPL se-Kabupaten Bantul sangat kuat, yaitu sebesar 0,702.

\section{Saran}

Berdasarkan hasil penelitian yang dilakukan, maka beberapa saran dapat dikemukakan berikut: (1) Untuk mendukung optimalisasi pemanfaatan inetrnet, perlu memperbanyak titik sumber tegangan dan titik akses internet di lingkungan sekolah untuk dipergunakan siswa baik melalui pemasangan accses point/ hot spot area ataupun dengan menyediakan komputer untuk dapat digunakan siswa mengakses internet secara gratis; (2) Mengoptimalkan keberadaan Musyawarah Guru Mata Pelajaran (MGMP) RPL di Kabupaten Bantul dengan mengadakan pelatihan dan workshop agar guru mampu mengoptimalkan fasilitas TIK dan kemampuan dalam e-writing dan $e$ reading sehingga proses e-learning dapat terlaksana secara baik; (3) Penggunaan model dan metode pembelajaran yang tepat oleh guru sangat diperlukan untuk diterapkan pada pendidikan teori maupun pendidikan praktik di laboratorium komputer; (4) Untuk penelitian lebih lanjut, perlu dimasukkan variabel intrinsik dan ekstrinsik lainnya, seperti variabel taraf ekonomi keluarga atau lingkungan sekolah sehingga diharapkan model regresi yang diperoleh akan lebih baik.

\section{DAFTAR PUSTAKA}

Alderman, M.K. (2004). Motivation for achievement possibilities for teaching and learning. New Jersey: Lawrence Elbaum.

Algifari, (2013). Analisis regresi teori, kasus, dan solusi. Yogyakarta: BPFE-Yogyakarta.

Arikunto, Suharsimi. (1999). Prosedur penelitian: Suatu pendekatan praktek. (4 $4^{\text {th }} \mathrm{ed}$.). Yogyakarta: Rineka Cipta.

Barakatu, A.R. (2007). Membangun motivasi berprestasi: pengembangan self efficacy dan penerapannya dalam dunia pendidikan [Versi Elektronik]. Lentera Pendidikan , 34-51.

Carmines, E.G. \& Zeller, R.A. (1979). Reliability and validity assesment. Thousand Oaks: Sage Publications, Inc. 
Hakam, Ulil. (2011). Konvergensi media dalam radio komunitas [Versi elektronik]. Jurnal Litbang, 13 (1). Diunduh 04 September 2013, dari http://balitbang.kominfo.go.id/balitbang/bppki-yogyakarta/files/2012/06/04-KonvergensiMedia-Dalam-Radio-Komunitas1.pdf

Horton, W. \& Horton, K. (2003). E-learning tool and technologies. Indianapolis: Wiley Publishing, Inc.

Katy, C. (2004). Effective writing for e-learning environments. Hershey: Information Science Publishing.

Keller, J.M. (1987). Development and Use of the ARCS model of motivational design [Versi elektronik]. Journal Of Instructional Development, 10, 2-10.

Kumar, S.A. \& Suresh, N. (2009). Operations management. New Delhi: New Age International Limited, Publisher.

Kurniawan, Bagus. (2014, Mei 19). 13 siswa SMA dan SMK di DIY tidal lulus UN. Diakses pada 8 Juli 2014, dari http:// news.detik.com/read/2014/05/19/ 160527/2586137/1536/13-siswa-smadan-smk-di-diy-tidak-lulus-un

Mills, S.C. (2006). Using the internet for active teaching and learning. Upper Saddle River: Pearson Education, Inc.

Muijs, D. (2004). Doing quantitative reseach in education with SPSS ( $1^{\text {st }}$ ed.). London: SAGE Publications, Ltd.

Neisser, U. (Ed.). (1993). The percieved self ecological and interpersonal sources of self-knowledge. New York: Cambrigde University Press.
Noor, A.R. (2011, September 1). Akses internet ideal 3 mbps. Diakses pada 5 September 2013, dari http://inet.detik.com/ $\operatorname{read} / 2011 / 09 / 01155911 / 1714429 / 137 /$

Purbo, O.W. (2007). Sejarah teknisi JARDIKNAS. Diunduh pada 28 Juli 2012, dari http://kambing.ui.ac.id/onnopurbo/library/library-ref-ind/ref-ind-2/application/education/jardiknas/Sejarah Teknisi Jardiknas.doc

Riduwan. (2008). Dasar-dasar statistika. Bandung: Alfa Beta.

Rowbotham, F., Galloway, L. \& Azhashemi, M. (2007). Operations management in context $\left(2^{\text {nd }} e d\right.$.). Burlington: Elsevier Ltd.

Sudjana. (1992). Metode statistika (5 $5^{\text {th }}$ ed). Bandung: Tarsito.

Sugiyono, (2006). Teknik penelitian. Yogyakarta: Pines.

Sugiyono, (2008). Metode penelitian kunatitatif kualitatif dan R\&D. Bandung: Alfabeta.

Suharjono, \& Hidayat, R. (2012, Mei 26). Tingkat kelulusan Bantul tertinggi seDIY. Diakses pada 3 Januari 2014, dari http://kampus.okezone.com/ $\mathrm{read} / 2012 / 05 / 26 / 373 / 635965 /$ tingkatkelulusan-bantul-tertinggi-se-diy/large.

Sujarweni, V.W. (2007). Belajar mudah SPSS untuk penelitian skripsi, tesis, desertasi \& umum. Yogyakarta: Ardana Media. 